\title{
The concept of knowledge and knowledge the management in the Romanian business field
}

\author{
Andreea Feraru, "Vasile Alecsandri” University of Bacau, Romania
}

\begin{abstract}
The concepts of knowledge and knowledge management have a significant position at the business level in Romania. Their importance is given by a created competitive advantage among organizations.

Such knowledge is lived and felt experience, the use that may lead to several results. Knowledge Management was developed as a philosophy and applications by companies, but it offers a number of concepts and models which can be expanded regionally to generate significant positive impact on regional development. That education and knowledge are considered assets of a business productive, as they may be primary factors in making a most valuable product or service.

The scope of knowledge management in Romania is the process that occurs in the organization and coordination of knowledge of each organization separately.
\end{abstract}

\section{Keywords:}

knowledge, explicit knowledge, tacit knowledge, knowledge economy, knowledge management,

In a society dependent on information, but also a larger number of organizations (as an expression of increased communication and complexity of social relations), knowledge seems to be the only power that guarantees social progress, economic and democratic while not eroding. Orientation to the capture and assimilation of knowledge is for most organizations the confirmation of a certain functional maturity, consistent with the essence of a informational company that is related. Knowledge information contained in a set of working practices, "theories in action", skills, processes and heuristics of the company's employees - are now "core" of assessing competence in informational globalized economy.

\section{The concept of knowledge}

Knowledge is defined, usually as the power to understand and capture the essence of the facts, recovery certainties and information obtained form of experiences and lessons. The operation of such organizations, are crucial processes designated by the generic term the "3 I", that innovation (creating new knowledge), instructing (learning) (assimilation of new knowledge) and interactive partnership for knowledge.

Knowledge is a concept that draws rule, much discussion and controversy. The information consists of organized data, while knowledge is the ability to use information effectively, giving him the meaning of "cognitive structures that guide action.

To know is to be able. Such knowledge is lived and felt experience, the use that may lead to several results. 
Knowledge is processed information, which may have a long existance, forward ideas and appear in a certain context, which determines their actual field to be used. As the deposit is not a resource management system, so a lot of information is not a knowledge management system. Usually, knowledge represent packages of information produced as a result of individual experiences, and may for this very reason, are most searched for product knowledge in a society in which exchange of data and information held with dizzying speed.

Using a Neil Flemming diagram we can say:

- a collection of data is not information;

- a collection of information is not knowledge;

- a collection of knowledge is not understanding;

- a collection of facts is understanding the truth.

\section{Types of knowledge}

According to specialists, Nonaka and Takeuchi, knowledge within an organization is classified into two categories

Explicit knowledge - can be explained in words and numbers. These can be easily communicated and distributed in the form of data, scientific formulas, codified procedures or universal principles. In turn this knowledge is classified into structured knowledge and nestructurte. Strucurate knowledge is composed of information, data, databases, spreadsheets. Adjoins unstructured knowledge in e-mail, images, video and audio selections.

Tacit knowledge-is personal and hard to formalize, dependent on experience and individual characteristics. They are less concrete than explicit knowledge, are difficult to access and often are not shared with other. In fact many people are unaware of the knowledge they possess or of value to others. As Michael Polanyi said: "We know more than we can say.

Polanyi is the founder of modern understanding of tacit knowledge. He sees knowledge as a process in which individual issues and culture interact, in other words the expression of all knowledge is impossible to builted in actual communication as to the facts of a person sitting individual experience.

If you classify knowledge according to the purpose and use, knowledge is divided into:

-Know what - this is the fundamental knowledge so that people / groups / organizations know what they know but do not know when and how they apply knowledge to solve problems.

-Know how - is its ability to transform the learned knowledge, knowledge from books, the actual results, tangible - in short, to know when to use specific knowledge to solve real problems.

-Know why - they go beyond the state "know how". This knowledge allows individuals to make a step towards "knowing how" and use knowledge, also having the ability to face unknown situations.

- Care-why - is self-motivated creativity of employees in a company. It is the only level that can not be supported by knowledge management system but may be supported by reasons or specific human resource management practices.

Paul David and Dominique Foray describe four major changes that have led to the knowledge society:

- Accelerating production of knowledge;

- Increase the share of intangible capital to micro and macroeconomic level;

- Innovation has become a dominant activity, and its sources, becoming more diverse;

- The revolution of instruments in using knowledge. 


\section{The importance of knowledge in knowledge-based economy}

Increasingly many academics, business people, but also policy-makers appreciate that type of company to which mankind is moving a knowledge society, supported by a knowledge economy.

The problems were highlighted by new skills and skills needed to integrate the knowledge economy, new geography in which physical distances are no longer constraints, conditions of access to knowledge and information on international, heterogeneous development of science and technology in various sectors, intellectual property rights and knowledge capitalization .

In this type of society, new economy, often called knowledge-based economy, owes its appearance to a number of important strengths that act today to change the meaning of business rules and national competitiveness: globalization, the intensity of use of knowledge and information, computer networks and connectivity, and increasing the share of workers with skills to over $80 \%$ of the employed population. Foundation knowledge economy concept was created by Peter Drucker. In 1966, he described the difference between the manual worker and the knowledge worker: a manual worker uses his hands to produce "things" and a knowledge worker uses his intelligence to produce ideas, knowledge and information.

Knowledge economy or knowledge economy is a concept that refers to using knowledge to produce benefits. Phrase popularized by Peter Drucker in his book The Age of Discontinuity (Drucker, 1969).

\section{Knowledge management in organizations}

Knowledge management field is a branch of knowledge management in charge of carrying out actions on knowledge (knowledge actions), such as organization, blocking, filtering, gathering, storing, sharing, dissemination and use of objects of knowledge (knowledge objects), identified as the information, data, experiences, evaluations, surveys and initiatives.

Knowledge Management involves capturing knowledge where knowledge is created by sharing it and its applications in a production process.

Knowledge Management was developed as a philosophy and applications by companies, but it offers a number of concepts and models which can be expanded regionally to generate significant positive impact on regional development.

This is due to the fact that developments in theoretical and applied knowledge management are congruent with the defining elements of the game competitive and competitive type prevalent in business life.

A key principle used is that education and knowledge are considered assets of a business productive, as they may be primary factors in making a most valuable product or service.

Knowledge Management, is obtaining the right of individuals to correct information in a timely manner so they can make the best decisions "(Gordon Petrash).

Knowledge Management is the identification and analysis of knowledge but also the necessary available knowledge and related processes, planning and subsequent control of actions to develop both knowledge and processes necessary to achieve organizational goals (J. Kingston, A. Macintosh).

The definition above implies the need for organizations to:

- capture and represent knowledge;

- $\quad$ share and reuse knowledge for different applications and different users, this implying that this knowledge should be available where it is needed;

- create a culture that encourages knowledge sharing and reuse. 
The scope of knowledge management in Romania is the process that occurs in the organization and coordination of knowledge of each organization separately. To every organization that process involves:

- Grouping knowledge on types of knowledge starting from the primary sources of the organization until the formation of internal memory.

- Storing knowledge seeking to knowledge stored in knowledge infrastructure of the efficient organization.

- Classification of knowledge for assessing and granting priorities that reflect the quality and adaptation of knowledge

- Selection of knowledge, which allows the user to use criteria for identifying the most appropriate knowledge.

- Disseminate knowledge, through which knowledge stored in various forms (tacit or explicit) are accessed by all members of the organization and even by its stakeholderi-customers, suppliers, etc.

Determined, we can say that knowledge management is not an end in itself. Businesses do not exist in order to propagate and advance knowledge - they exist to sell products and services.

Knowledge management within firms is existing since always in the form of discussions between team mates or by organizing various trainings. Nowadays, the concept is applied in a formally organized way, within specialized departments and by the performant IT systems support

In developing knowledge based management systems must consider some principles of knowledge management:

$>$ The efficient management of knowledge requires taking into account both people and technology

$>$ Implementing knowledge management requires knowledge-based managers.

$>$ Leadership is essential

$>$ Knowledge management requires improved processes that involve working with knowledge

$>$ Knowledge management is never ending process;

$>$ Knowledge management requires a contract that covers knowledge (eg intellectual property rights)

$>$ Knowledge management requires teaching

$>$ Knowledge management practice is dependent on technology

$>$ Knowledge management is a process, not a product.

\section{References:}

1. Bratianu, C. (2003) Managementul strategic. Editia a 3-a. Craiova, Editura Universitaria.

2. David P. A. \& Foray D. (2005) Economic Fundamentals Of the Knowledge Society, Oxford University Press.

3. Drucker, P. (1988) The coming of the new organization, Harvard Business Review.

4. Drucker, P. (1969) The Age of Discontinuit, Harvard Business Review.

5. Kingstone J., Macintosh A.(2003) Models of Trust for Knowledge-Based Government Services, Springer Berlin.

6. Nicolescu O., Nicolescu L. (2005) Economia, firma si managementul bazate pe cunostinte, Bucuresti, Editura Economică.

7. Nonaka, I., Takeuchi, H. (1995) The Knowledge Creating Company: How Japanese Companies Create the Dynamics of Innovation. Oxford University Press, New York.

8. Petrash G. (2002) Knowledge Management. Classic and Contemporary works, Masschusetts Institute of Tehnology.

9. Polanyi, M. (1983) The tacit dimension. Gloucester: Peter Smith. 
Studies and Scientific Researches - Economic Edition, no. 14, 2009

10. Rosca, I. Gh. (ed), (2006) Societatea cunoasterii. Bucuresti, Editura Economica. 